\title{
Children's Rights Implementation as a Multi-Level Governance Process
}

\begin{abstract}
In this article, I suggest to view children's rights implementation as a multi-level governance process. I argue that a multi-level framework usefully integrates earlier work on norm compliance from International Relations (IR) scholarship and on norm vernacularization brought forward in Anthropology. Governance concepts move a step forward because they horizontally and vertically broaden the state-centric IR literature. After developing this multilevel analytical framework, I introduce an in-depth case study on children's rights implementation in Bangladesh. This case demonstrates that particularly in weak states, where capacities are lacking, multi-level activities are relevant for transporting global norms to the societal local rights-holders.
\end{abstract}

\section{Introduction}

The world has commemorated the $25^{\text {th }}$ anniversary of the United Nations (UN) Convention on the Rights of the Child (CRC) in November 2014. Only a month later, two children's rights activists from South Asia, Malala Yousafzai and Kailash Satyarthi, have been awarded the Nobel Peace Prize. Both laureates have "contributed to the development of important international conventions on children's rights"1. Children's rights conventions have indeed been path-breaking in several respects: on the one hand, they promoted the concept of the child as an individual and autonomous rights-holder. And on the other hand, they achieved the widest ratification rate among all human rights treaties in the UN system. But have they led to an overall improvement of the situation of those they were made for? Did they indeed initiate a change in the lives of the children themselves? 
Reports published on a regular basis by specialized agencies of the UN working on children's rights point to the fact that, at the grassroots level, children's situation regarding education, health, nutrition or child labor is progressing very slowly; it is often stagnating or even deteriorating. Particularly in weak states, governments often fail to meet the complex obligations to respect, protect and fulfill that come hand in hand with ratifying human rights treaties. In this article, I will focus on how to understand (and overcome) the discrepancy between governmental acceptance of global human rights norms and societal compliance with these norms at the local level in weak states. Here, weak states are understood as states in which the government bears the monopoly of state power but faces serious limitations in exercising its functions pertinent to the rule of law, legitimacy and providing welfare services $^{2}$. This means that weak states are characterized by a lack of capacity to domestically implement central decisions. Governing these areas of limited statehood, according to Risse, "[...] rests on the systematic involvement of nonstate actors [...] and is 'multilevel governance', which links the local with national, regional, and global levels [...]”3.

The central research question dealt with in this article is under which conditions, with the help of what social mechanisms ${ }^{4}$ and under participation of which actors global children's rights become effective for their local societal rights-holders. I point out that human rights implementation, comprising all steps between governmental ratification and societal compliance, is a multi-level governance process. After norms emerge at the international level, implementation has to take place at the national but also at the local level. A national implementation process is primarily directed at the norm addressees, i.e. the ratifying state government, whereas the local implementation process has to reach the norm targets, i.e. the societal rights-holders. National norm implementation has already been treated in greater depth within International Relations' (IR) socialization and compliance research ${ }^{5}$. Yet, less attention was paid to local implementation processes. Although some work has been 
published on norm localization ${ }^{6}$, only scarce research takes into account how these different levels - the global, the national and the local - are interlinked ${ }^{7}$. I argue that even norm localization processes are influenced by the agendas (and conventions) of international organizations (IOs). This means that a multi-level governance framework is best suited to comprehensively grasp rights implementation.

In this article, I apply a multi-level governance framework to a case study on children's rights in Bangladesh. Diving deep into the empirical material, I inductively generate hypotheses on relevant social mechanisms and multi-level actor cooperation to understand what happens after state ratification to reach the societal rights-holders. Children's rights are particularly relevant for analyzing the research question raised because they clearly display the discrepancy between global norm ambitions and local realities. The CRC is known as the most widely ratified human rights treaty with 195 Member States accepting it as legally binding within their territory ${ }^{8}$. Nevertheless, current reports published by IOs concerned with children's rights realization, like the United Nations International Children's Emergency Fund (UNICEF) and the International Labour Organization (ILO), demonstrate that the rights situation of children, especially in weak states, improves only slowly and is often stagnating 9 . Bangladesh is a typical case proving this discrepancy; its implementation problems are also representative for other country cases ${ }^{10}$. The South Asian state has ratified the most important children's rights conventions and harmonized its national legislation accordingly ${ }^{11}$. A change of the children's rights situation at the local level, however, only came into being very slowly. Policy programs launched by governmental or non-governmental organizations and targeted at the rights-holders, i.e. the children and their families or communities, played an important role for initiating this local change. In Bangladesh, a variety of children's rights policies and programs, including projects of UNICEF, the ILO, the government, local NGOs and trade unions, are in place. It is also the only country case, in which UNICEF and the ILO (usually 
following a different approach towards children's rights) have cooperated in an exceptional project endeavor initiating a multi-level partnership for children's rights implementation. Therefore, Bangladesh can be regarded as a unique case. The different implementation programs comparatively analyzed here can be understood as sub-cases of the case study. Due to the different approaches pursued in the programs, i.e. the establishment of micro-credit systems, the provision of informal education in community centers, the removal of hazards from children's work places or the promotion of skills-training and self-employment, variance in the independent variables (mechanisms leading to societal compliance) is provided for. I mainly selected Bangladesh as a case study because it - compared to other weak states displayed the greatest diversity in children's rights programs and therefore, constitutes a case from which one can learn a $\operatorname{lot}^{12}$. In an in-depth empirical analysis, I will take a closer look at the successes gained from these programs and investigate how they came into being.

Within the framework of process tracing ${ }^{13}$, I comparatively analyze seven programs initiated either by the government, by a non-governmental organization (NGO) or by an IO. The empirical analysis is based on data gathered from comprehensive field research in Bangladesh that I evaluated utilizing method triangulation ${ }^{14}$. The evaluation methods applied here comprise a qualitative content analysis of evaluation reports, of transcripts from expert interviews ${ }^{15}$ conducted with representatives from IOs, Bangladesh's government and local NGOs, and of field notes from observing certain project components. I also interviewed children, parents and key community actors as the target group of children's rights (and these projects) themselves. They, however, have been careful in voicing concerns about initiatives that were launched in cooperation with IOs or the government. Hence, the most valuable statements on local implementation could be gained from expert interviews with local civil society taking a key role in these processes. For comparing the seven projects, I applied a Qualitative Comparative Analysis (QCA $)^{16}$. Thus, the methods employed also reflect the 
multi-level and multi-disciplinary research framework. Whereas some of these research methods are typically utilized by Political Scientists and IR scholars, such as expert interviews, document and content analyses ${ }^{17}$, field observations or participatory methods at the grassroots level are rather applied by Anthropologists or Development Sociologists ${ }^{18}$. With the combination of both, a wide-ranging picture of children's rights implementation in Bangladesh shall be drawn.

In the following section of this article, I introduce major children's rights conventions and I carve out the empirical discrepancy between high ratification rates of these treaties and an often stagnating rights situation on the ground. In a next step, I show that a multi-level governance framework is useful for comprehensively understanding this discrepancy by integrating important aspects of existing scholarship from IR and from Sociology, Anthropology and Development studies. Following upon that, I introduce the case study in which I have traced approaches of local rights realization including multi-level policy programs and actor constellations. Finally, I conclude by generating hypotheses that I introduce in a multi-level model on children's rights implementation in weak states.

\section{The Discrepancy between Global Norm Ambitions and Local Change}

Global ambitions on child protection are primarily marked by three international conventions: the CRC, the ILO Minimum Age Convention (MAC) and the ILO Worst Forms of Child Labor Convention (WFCL). All of these instruments do not only comprise detailed legislative provisions but also stipulate flexible guidelines and principles ${ }^{19}$. The CRC adopted in 1989, for instance, contains concrete rights, like the right to education (Art. 28) and health (Art. 24), but also promotes broader principles, such as primary consideration of the best interests of the child (Art. 3) and the right to participation (Art. 12) ${ }^{20}$. These principles help to interpret the 
convention and serve as guidelines for translating legal standards into national policies and implementation programs ${ }^{21}$.

The MAC, adopted in 1973, also embraces a flexible approach: It demands ratifying governments to create their own national policy on an appropriate minimum age for taking up employment (Art. 1). This shall not be set below the age at which schooling is compulsory, not below the age of 15 years in developed countries and not below the age of 14 years in developing countries (Art. 2.3, Art. 2.4). Exceptions are formulated for light work, which in developing economies is already allowed at 12 years (Art. 7.4), and hazardous work, which can only be taken up at the age of 18 years (Art. 3.1) ${ }^{22}$. Within the range of these benchmarks, state actors can determine their own policy strategy.

The youngest legal instrument in the global child rights regime is the WFCL that was adopted in 1999. This is the first convention that does not condemn child labor but places an emphasis on eliminating its worst forms. This relates to all economic activities that jeopardize children's physical and mental development (Art 3.d). Whereas slavery and forced labor, the recruitment of children for armed conflict, pornography, prostitution and further illegal activities, belong to the unconditional worst forms, each Member State also has to define its own country-specific forms of hazardous child labor (Art. 4$)^{23}$. This means, the convention invites ratifying states to create their own national policies concentrating on abolishing the worst forms of child labor. With this new consensus, the WFCL became the first instrument that was unanimously passed at an International Labour Conference. At the same time, it achieved the fastest ratification rate in the history of the $\mathrm{ILO}^{24}$.

Ratification rates can be viewed as indicator for an acceptance of human rights norms, at least at an official level. The CRC is known as the rights instrument with the widest recognition. Today, 195 countries have legally committed to it ${ }^{25}$. The WFCL has received similar approval: 179 out of 185 ILO Member States have ratified it until today ${ }^{26}$. This ratification 
boost also fostered further acceptance of the previous ILO child rights instrument, the MAC. It has - by now - been ratified by 168 ILO Member States ${ }^{27}$. Since the adoption of the WFCL, both ILO conventions have functioned like a tandem: states that ratified one of them, usually also ratified the other.

Despite the fact that a broad global consensus pertinent to children's rights treaties seems to exist $^{28}$, an empirical gap between global ambitions and local realities can be observed. This is particularly true in developing countries. The UN, especially those organizational units concerned with child protection, UNICEF and the ILO's International Programme on the Elimination of Child Labour (IPEC), regularly deliver empirical data on the local rights situation proving this discrepancy. New global estimates on child labor published by IPEC, the program responsible for implementing the WFCL and the MAC, reveal that progress in eliminating child labor could be achieved. Nevertheless, there are still about 168 million child laborers, i.e. about 10 percent of the world's children. Moreover, approximately 85 million children are still occupied in hazardous work that is detrimental to their physical and mental development $^{29}$. Latest figures from UNICEF, the agency responsible for implementing the CRC, show a similar trend: There are improvements in the rights situation but these come at a very slow pace. In 2012, the estimated number of children who died under five years of age was still at 6.6 million $^{30}$. Pertinent to education, UNICEF and UNESCO even declare that "[...] progress has stagnated $[\ldots]$ " and that "the unfinished education agenda" needs to be addressed: Until today, there are still about 57 million children not enrolled in primary schools $^{31}$. This empirical evidence is in line with established research in International Relations (IR) that considers human rights ratification as a "paradox of empty promises"32.

In the following section, I will dive deeper into explanations for this discrepancy brought forward by International Relations scholarship and other disciplines engaged in childhood studies, such as Sociology, Anthropology and Development Studies. 


\subsection{Explanations from International Relations Scholarship}

In IR scholarship, norms are grasped as " [...] collective expectations about proper behaviour for a given identity"33. Human rights are particular types of norms that define the relationship between a state and its citizens - and that increasingly also regulate the behavior of business actors and NGOs ${ }^{34}$. Norm research in IR has pointed to conceptual differentiations between „,norm adoption“ and „,norm internalization“35 or between a „prescriptive status“ and „normconsistent behavior، ${ }^{636}$. All of these conceptualizations carve out the empirical difference between formally ratifying an international treaty and state actors behaving according to the norms anchored in this treaty. State actors do not necessarily have to be convinced of a human rights norm when they ratify it. Instead, they could merely demonstrate commitment due to external pressure, conditions for foreign aid or for advancing opportunities for international cooperation. Hence, states can de jure adopt a norm, without de facto respecting it. Whereas norm socialization research focuses on the adoption of international norms by governments, compliance research delivers more insights into mechanisms fostering adherence to these norms ${ }^{37}$. Therefore, research on norm compliance can provide useful explanations for the processes that advance conformity of both, state and societal actors, with international treaties.

Compliance scholars start from the assumption that norms have already been adopted and concentrate on social mechanisms that guarantee obedience to these rules. Chayes, Chayes and Mitchell, for instance, “[...] use compliance to describe those instances when an actor's behavior conforms to an explicit rule of a treaty"38. Factors advancing compliance are monitoring and sanctioning, juridification, and legal as well as civil internalization, but also discourse and persuasion ${ }^{39}$. Another important mechanism is compliance management. This includes capacity-building, the provision of administrative, technological and financial resources but also the delivery of relevant information. Among other sub-mechanisms that 
have to be considered, effective cooperation between state and non-state actors play a significant role in compliance management ${ }^{40}$. In compliance research, there is a differentiation between mechanisms directed at state actors to foster rule conformity among norm addressees and mechanisms directed at society to foster rule conformity among norm targets. Participation opportunities in rule-making and the social acceptance of regulations are important mechanisms contributing to norm compliance within society ${ }^{41}$. Considering participation and social acceptance, however, is not enough for understanding local societal compliance with international (human rights) treaties. More about local societal processes towards compliance can be learned from scholarship originating in other Social Science disciplines.

\subsection{Insights from Anthropology, Sociology and Development Studies}

In childhood studies, an important bulk of empirical research has been conducted at the disciplinary intersection of Anthropology, Sociology and Development Scholarship. Various analyses investigating the situation of children in developing countries suggest that a comprehensive understanding of the local context is an essential prerequisite for implementing global rights therein. Scholars emphasize that global norms need „local emphasis, refurbishing and interpretation" ${ }^{\prime 42}$ to become meaningful in a particular context.

Jo Boyden and colleagues argue that what is needed to design appropriate policies is not only a contextual knowledge of children's reality, but knowledge provided by the children themselves ${ }^{43}$. In line with this argument, children are viewed as social agents shaping their own environment. Children shall be participating subjects who need to be personalized and individualized $^{44}$.

Although not concerned with the implementation of children's rights but with the protection of women, the work of Sally Engle Merry has been path-breaking in explaining how global 
rights become meaningful in local contexts. Merry introduces the concept of vernacularization as the adaptation of global norms to local communities, their institutions and their meanings ${ }^{45}$. Key to vernacularization processes are the agents that connect behavioral standards codified in international law with local realities. Merry refers to these intermediaries as people who engage at various levels. They can be activists of a social movement, lawyers, NGO leaders, academics or others that: "[...] have one foot in the transnational community and one at home" ${ }^{, 46}$. This means that they need to apply the language of IOs and external donors but, at the same time, reach out to the local norm targets. Intermediaries "indigenize" meanings; they make them comprehensible within prevalent cultural terminology, traditions, and practices $^{47}$. Often, NGOs take the positions of intermediaries: they have legal expertise, they know the human rights system, the language of pertinent conventions ${ }^{48}$ and they have access to the local target populations. Their efforts become even more important in the absence of state commitment or lacking state functions.

\subsection{Children's Rights Implementation as a Multi-level Governance Process}

In this article, I argue that both perspectives, i.e. compliance focusing on norm adherence by state actors and vernacularization emphasizing norm adaptation by society, can usefully be integrated into a multi-level governance framework. With James Rosenau's pioneering definition, it has been suggested to grasp governance as: "[...] systems of rule at all levels of human activity - from the family to the international organization - in which the pursuit of goals through the exercise of control has transnational repercussions" ${ }^{\prime 49}$. This definition does not only emphasize different levels of human activity but also refers to various actors that might be relevant in the pursuit of goals - and these are governmental, e.g. international organizations, and societal ones, e.g. the family. 
A multi-level governance framework offers two major advantages in the study of human rights implementation. First, it provides for horizontal and vertical diversification to the predominantly state-centric socialization and compliance scholarship in IR. The vertical governance dimension is strongly influenced by EU studies paying attention to governing at the supranational, national, regional and local level ${ }^{50}$. It is useful for studying rights implementation processes because here, competences and resources are also shared across territorial levels and actors operating at these various levels have to coordinate their decisions $^{51}$. The vertical governance dimension points to a plurality of actors that carry out governance functions through less formalized and more flexible arrangements, partnerships, networks, and projects ${ }^{52}$. Non-state actors, like NGOs or even private businesses, become involved in providing public goods in a demand-tailored and efficient way whenever governmental institutions cannot meet the challenges of complexity in modern societies and/or lack the necessary capacities and resources like in weak states. Thus, a state-centered understanding of politics has shifted towards a society-oriented perspective in which non-state actors become meaningful protagonists. This society-oriented perspective is particularly relevant when considering how global human rights reach their local societal target group. Second, a multi-level governance framework underscores that governance levels and pertinent actors do not operate independent of each other. In contrast, they are mutually dependent and each level's actors perform particular functions which points to at least "[...] some extent [of] functional differentiation" ${ }^{, 53}$. This means that a multi-level perspective moves one step beyond recent work on norm vernacularization and norm localization ${ }^{54}$. It highlights how particularly in weak state contexts - local human rights implementation is influenced by multi-level policy programs and multi-level actor constellations ${ }^{55}$. Table 1 highlights this theoretical framework with a focus on multi-level processes that guide local implementation. 
Table 1: Analytical Framework

\begin{tabular}{|c|l|l|}
\hline The Vertical & \multicolumn{1}{|c|}{$\begin{array}{c}\text { Governance } \\
\text { Norms }\end{array}$} & The Horizontal \\
\hline Global & \multicolumn{1}{|c|}{ Conventions } & Governmental \\
\hline National & $\begin{array}{l}\text { National Implementation: } \\
\text { (Constitution, Legislation, } \\
\text { Policies) }\end{array}$ & $\begin{array}{l}\text { Local Actors and Multi-level } \\
\text { Actor Arrangements }\end{array}$ \\
\hline Local & $\begin{array}{l}\text { Local Implementation } \\
-\quad \begin{array}{l}\text { Multi-level policy } \\
\text { programs reaching out } \\
\text { to the norm target } \\
\text { group }\end{array}\end{array}$ & \\
\hline
\end{tabular}

\section{Children's Rights Implementation as Multi-level Process: An In-Depth Case Study}

The Government of Bangladesh (GOB) ratified the 1989 CRC in August 1990 and hence, belonged to the first signatory countries of the international community ${ }^{56}$. Furthermore, it legally committed itself to the 1999 WFCL, relatively soon after its adoption in March $2001^{57}$. As a consequence of ratification, Bangladesh initiated legislative reforms in order to harmonize national law with fundamental norms brought forward in both conventions.

Following ratification of the CRC and signing the World Declaration on Education for All (also in 1990), the government adopted a national Primary Education Act during the same year $^{58}$. Building upon that, it institutionalized a reformed primary school system, introducing obligatory primary education in the country ${ }^{59}$. These legislative reforms are also reflected in several policies relevant for education, among them the National Plan of Action I and II (1992-2000 and 2003-2015), several National Education Policies (the latest adopted in 2010), a National Plan of Action for Children (2005-2009) and a National Children Policy from 2011. Governmental investment into the reformed primary education system rose enormously from 4.7 percent of total public spending in the fiscal years between 1993 and 1994 to 19.9 
percent in the years between 1997 and $1998^{60}$. Within a period of two years, from 1992 to 1994, the primary enrollment rate increased by 35 percent, with a particularly significant growth for girls of 44 percent $^{61}$. The efforts of the government led to a primary school net enrollment rate of 93 percent for girls and 86 percent for boys ${ }^{62}$. This means that not only state actors comply with the right to education but it has also reached its local rights-holders, the children. Bangladesh will most certainly achieve the second Millennium Development Goal, i.e. universal primary education, until 2015.

The right to health is similarly promoted by a multitude of policy strategies. The Fifth Five Year Plan (1997-2002) formulated the objective of ensuring universal access to quality health care services for all citizens of Bangladesh. Here, the need to reduce infant and maternal mortality and to improve their nutritional status was emphasized. Another five-year program, launched in 1998 as the Health and Population Sector Programme (HPSP), acknowledges adolescents as one priority target group. The HPSP made provisions for the delivery of an Essential Services Package (ESP) that comprises basic reproductive and child health services, including family planning, maternal care, and immunization ${ }^{63}$.

After completing the ratification process of the WFCL in 2001, it took about five years to legally institutionalize the basic norms anchored therein. In the year 2006, the Bangladesh Labor Code was introduced, which finally harmonized and consolidated the bulk of partly controversial national labor laws in force. The Code, also known as the Bangladesh Labor Act, prohibits all forms of child labor under 14 years of age. It also protects youths over 14 years from the worst forms of work ${ }^{64}$. In addition to the Labor Act, the GoB finally passed a National Child Labour Elimination Policy in 2010. This policy is a follow-up requirement of admission to the WFCL. The main objectives of the policy are to withdraw children from the worst forms of child labor, to engage their parents in income-generating activities, to offer 
stipends for (re-)integrating children in schools and to raise awareness among society to eliminate several forms of child labor by $2015^{65}$.

Prior to some of these crucial labor law reforms and the 2010 National Child Labour Elimination Policy, several policy programs fostering children's rights at the local level had already been initiated. These will be analyzed in the following. Three fundamental norms stipulated in the CRC and the WFCL (and in the programs examined) are emphasized in this case study, namely (1) protection from the worst forms of child labor, (2) the right to education and (3) the right to health. Thus, projects were considered in the pool of sub-cases if they met at least one of the following indicators: (1) a targeted number ${ }^{66}$ of children was withdrawn from hazardous work places or the hazards were removed from their places of work, (2) a targeted number of children was provided with non-formal education and skills training or integrated into governmental schools, (3) a targeted number of children was provided with basic health care services. This means the definition (and operationalization) of success is focused on the societal rights target group, i.e. the children and their families themselves, and less on activities of the rights addresses, i.e. state actors adopting laws and policies.

Altogether, seven sub-cases ${ }^{67}$ were comparatively investigated within the framework of a process analysis. These are:

- the Child Labour Elimination Project: CLEP (initiated and realized by an NGO),

- the Food for Education Programs: FFE and the consecutive Primary Education Stipend Project: PESP (both initiated and realized by the government),

- the Eradication of Hazardous Child Labour: EHCL project (initiated by Bangladesh's Ministry of Labour and Employment (MoLE) and realized by local NGOs), 
- the Basic Education for Hard to Reach Urban Working Children: BEHTRUWC project (initiated by UNICEF in cooperation with the Ministry of Primary and Mass Education (MoPME) and implemented by local NGOs),

- the Preventing and Eliminating the Worst Forms of Child Labour in Selected Formal and Informal Sectors in Bangladesh: ILO/IPEC USDoL ${ }^{68}$ project (initiated by the ILO and the MoLE and realized by local NGOs),

- the Prevention and Elimination of Selected Worst Forms of Child Labour in the Informal Economy in Dhaka City: ILO/IPEC Net ${ }^{69}$ project (initiated by the ILO and the MoLE and realized by local NGOs),

- and the Bangladesh Garment Sector Projects: BGMEA/ILO/UNICEF (initiated by UNICEF and the ILO, the Bangladesh Garments Manufacturers and Exporters Association (BGMEA), the MoLE and realized by NGOs).

Table 2 summarizes how program success referring to children's rights implementation was defined along the dimensions of output and outcome ${ }^{70}$. It presents implementation success as a four value set. Four value sets are used in QCA fuzzy set analyses to not only demonstrate in a dichotomous way what is "in" and what is "out", but to be more precise in what is "more out than in," "neither fully in nor fully out" or "more in than out"71. This is also helpful for defining implementation success among the sub-cases considered here. If only one indicator is met, the project is considered to be "less successful". If at least two of three implementation indicators are met, the project is considered to be "more successful". This decision has been made taking a human rights perspective into account. Due to the interrelatedness and mutually reinforcing character of human rights, those projects that do not only withdraw children from hazardous occupations but also provide them with viable education alternatives are considered to be more successful. Those programs that do not only deliver education services but also protect children from the worst forms of child labor and take care of basic health care at the 
same time, are viewed to have the best effect on the children. Table 2 summarizes these considerations of implementation success also providing some concrete numbers regarding the outcome on the rights targets. 
Table 2: Implementation Success of Policy Programs

\begin{tabular}{|c|c|c|c|c|c|c|c|}
\hline $\begin{array}{l}\text { Project } \\
\text { Implementatio } \\
\text { Success }\end{array}$ & CLEP & FFE/PESP & EHCL & BEHTRUWC & $\begin{array}{l}\text { ILO/IPEC } \\
\text { USDoL }\end{array}$ & ILO/IPEC Net & $\begin{array}{l}\text { BGMEA/ILO/ } \\
\text { UNICEF }\end{array}$ \\
\hline $\begin{array}{l}\text { Output } \\
\text { (according to } \\
\text { indicators) }\end{array}$ & 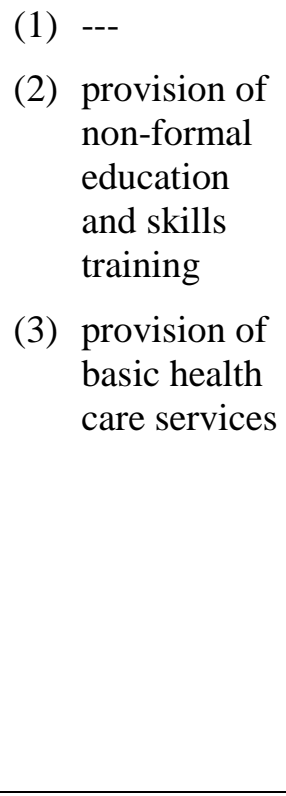 & $\begin{array}{l}\text { (1) } \begin{array}{l}--- \\
\text { (2) }\end{array} \text { regular } \\
\text { provision of } \\
\text { governmental } \\
\text { primary } \\
\text { education } \\
\text { (3) --- }\end{array}$ & 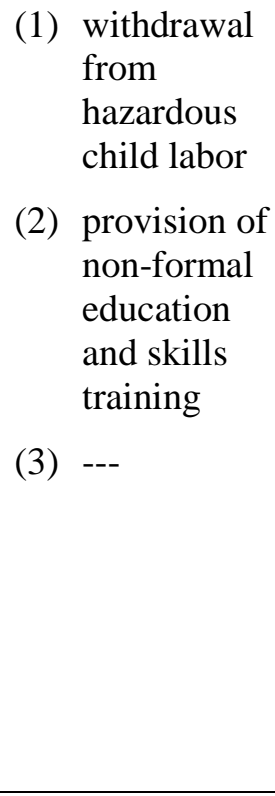 & 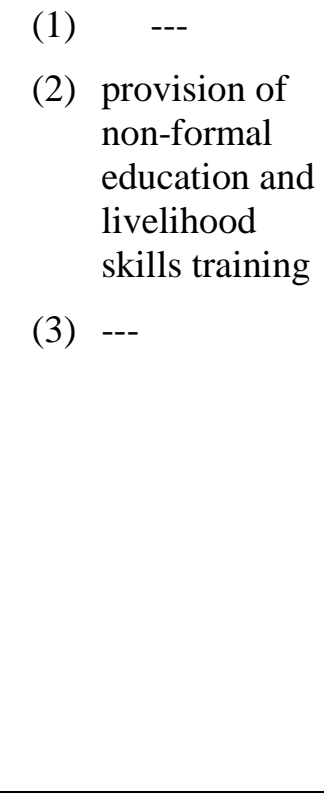 & $\begin{array}{l}\text { (1) } \begin{array}{l}\text { withdrawal } \\
\text { from } \\
\text { hazardous } \\
\text { child labor }\end{array} \\
\text { (2) } \begin{array}{l}\text { provision of } \\
\text { non-formal } \\
\text { education and } \\
\text { skills training }\end{array} \\
\text { (3) } \begin{array}{l}\text { provision of } \\
\text { basic health } \\
\text { care services }\end{array}\end{array}$ & $\begin{array}{l}\text { (1) withdrawal } \\
\text { from } \\
\text { hazardous } \\
\text { child labor } \\
\text { and } \\
\text { workplace } \\
\text { improve- } \\
\text { ment to } \\
\text { reduce } \\
\text { hazards } \\
\text { (2) provision of } \\
\text { non-formal } \\
\text { education and } \\
\text { skills training } \\
\text { (3) provision of } \\
\text { basic health } \\
\text { care services }\end{array}$ & 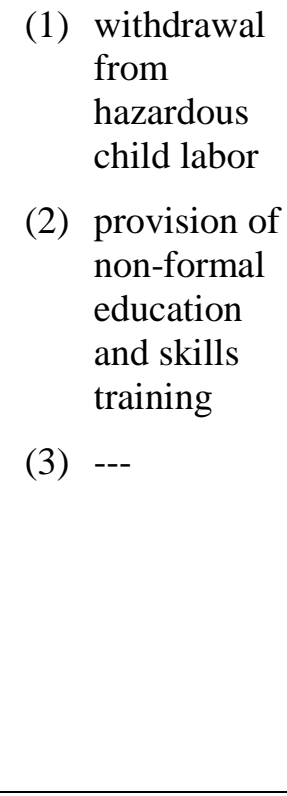 \\
\hline Outcome & $\begin{array}{l}\text { (1) } \quad \text {--- } \\
\text { (2) between } \\
\text { 2002-2008: } \\
1386 \\
\text { graduates } \\
\text { from NFE } \\
\text { and 3144 }\end{array}$ & $\begin{array}{l}\text { (1) } \\
\text { (2) between 1993- } \\
\text { 2008: FFE: } 2.1 \\
\text { million } \\
\text { beneficiary } \\
\text { students } \\
\text { (2002), PESP: }\end{array}$ & $\begin{array}{l}\text { (1) indefinite } \\
\text { number of } \\
\text { children } \\
\text { withdrawn } \\
\text { from } \\
\text { hazardous } \\
\text { child labor }\end{array}$ & $\begin{array}{l}\text { (1) } \\
\text { (2) between } \\
\text { 1997-2009: } \\
517,150 \\
\text { children } \\
\text { provided with } \\
\text { non-formal }\end{array}$ & $\begin{array}{l}\text { (1) between } 2000 \text { - } \\
\text { 2003: } 8,826 \\
\text { children } \\
\text { withdrawn } \\
\text { from } \\
\text { hazardous } \\
\text { work and } 353\end{array}$ & $\begin{array}{l}\text { (1) between } \\
\text { 2001-2006: } \\
12,032 \\
\text { children } \\
\text { withdrawn }{ }^{76} \text {, } \\
200 \\
\text { workplaces }\end{array}$ & $\begin{array}{l}\text { (1) between } \\
\text { 1995-2003: } \\
\text { 5,674 child } \\
\text { laborers } \\
\text { identified } \\
\text { during child } \\
\text { collection }\end{array}$ \\
\hline
\end{tabular}




\begin{tabular}{|c|c|c|c|c|c|c|c|c|c|c|}
\hline & $\begin{array}{ll}\text { from SDT } & \\
\text { (3) } & \text { indefinite } \\
\text { number of } \\
\text { beneficiaries } \\
\text { make use of } \\
\text { health care } \\
\text { services }\end{array}$ & $\begin{array}{l}5,5 \text { million } \\
\text { beneficiary } \\
\text { students } \\
(2008){ }^{73} \text { increa } \\
\text { sed school } \\
\text { enrollment, } \\
\text { attendance and } \\
\text { duration, } \\
\text { reduced drop } \\
\text { outs } \\
\text { (3) --- }\end{array}$ & $\begin{array}{l}\text { (2) indefinite } \\
\text { number of } \\
\text { children } \\
\text { provided } \\
\text { with non- } \\
\text { formal } \\
\text { education } \\
\text { (3) --- }\end{array}$ & $\begin{array}{l}\text { education of } \\
\text { which } \\
166,150 \\
\text { received } \\
\text { livelihood } \\
\text { skills } \\
\text { training }{ }^{74} \\
\text { (3) --- }\end{array}$ & (2) & $\begin{array}{l}\text { child domestic } \\
\text { workers with } \\
\text { safer working } \\
\text { conditions } \\
19,191 \\
\text { children } \\
\text { provided with } \\
\text { non-formal } \\
\text { education } \\
30,175 \\
\text { children have } \\
\text { received } \\
\text { counseling, } \\
\text { health and } \\
\text { referral } \\
\text { services }\end{array}$ & (2) & $\begin{array}{l}\text { improved }^{77} \\
20,000 \\
\text { children } \\
\text { successfully } \text { completed } \\
\text { NFE, }{ }^{78} 1,282 \\
\text { children } \\
\text { graduated } \\
\text { from the old } \\
\text { and } 180 \\
\text { children from } \\
\text { the new SDT }_{\text {program }}{ }^{79} \\
\text { health status } \\
\text { and } \\
\text { awareness of } \\
\text { NFE and } \\
\text { SDT } \\
\text { graduates } \\
\text { improved }^{80}\end{array}$ & $\begin{array}{l}\text { (2) } \\
\text { (3) } \\
\end{array}$ & $\begin{array}{l}\text { drive in } \\
1996 ;^{81} \\
3,290 \\
\text { children } \\
\text { withdrawn } \\
\text { from } \\
\text { garment } \\
\text { industries } \\
\text { (from } 1998 \\
\text { on) } \\
8,588 \\
\text { children } \\
\text { enrolled in } \\
\text { NFE }^{83} \text { and } \\
\text { about } 2,035 \\
\text { children } \\
\text { absolved } \\
\text { skills } \\
\text { training } \\
\text {--- } \\
\end{array}$ \\
\hline $\begin{array}{l}\text { Implementation } \\
\text { Success }\end{array}$ & more successful & less successful & more successful & less successful & & successful & & successful & & re successful \\
\hline
\end{tabular}


Taking a closer look at the quantitative data provided in this table, one could, of course, argue that programs like the FFE/PESP reaching out to 5.5 million children cannot be categorized as less successful. This is true with respect to the right to education fostered through this initiative. At the same, field research at the grassroots level disclosed that education alone often does not improve the children's rights situation comprehensively. Bangladesh, for instance, for a very long time faced a serious child mortality rate ${ }^{85}$ often related to malnutrition or other health issues. And if a child falls sick, it cannot attend school anymore. Thus, in this research project implementation success was defined in this multi-dimensional way focusing on the three major rights mentioned above.

In the following, a systematic comparison of programs strategies will be presented which constitutes the empirical basis for generating hypotheses on local rights implementation. It is important to note that the comparison takes the relative success of the programs into account using Boolean Algebra ${ }^{86}$. Hence, similarities and differences regarding (1) infrastructure and institutions, (2) social mechanisms and (3) actors (with a focus on necessary and sufficient conditions) will be outlined. The empirical results will be presented in a qualitative description here - fleshed out with illustrative examples from the respective projects.

\subsection{Infrastructure and Institutions}

A necessary condition for local rights implementation in a weak state like Bangladesh is the establishment of an infrastructure through which rights-related education and health services can be delivered to the children and their parents. All of the projects analyzed here set up an infrastructure, except for the FFE/PESP programs, which distributed food and stipends in already existing governmental and non-governmental schools.

Before the respective programs were launched in Bangladesh such an infrastructure was often missing, particularly in disadvantaged rural and urban areas, in which the rights of children 
were also neglected. Here, the state lacked the required resources and capacities to build up schools or hospitals ${ }^{87}$. As a consequence, all of the programs investigated (except for the one reverting to existing schools) commenced their initiatives with establishing so-called community learning centers in their respective target areas ${ }^{88}$. Through these centers they could, in a second step, offer certain rights-relevant social services, such as non-formal education $^{89}$, vocational training, but also immunizations, the supply of medicines and nutrition support, especially for working children and their families. The program initiated by UNICEF (BEHTRUWC), for instance, managed to set up 6646 learning centers in the urban slums of all of Bangladesh's seven big cities, i.e. Dhaka, Chittagong, Khulna, Barisal, Rashjahi, und Sylhet between 2005 and $2012^{90}$.

The need for infrastructure in remote areas is, of course, not new to development research; a new result of this case study is rather how provisional and cost-effective it can be. In the subcases analyzed, local implementing NGOs familiar with the target areas searched for rooms or buildings in the urban slums and rented these as school centers. One interesting example is offered by the governmental EHCL program: Within its framework, working children met in very simple rooms or bamboo huts that were - due to lacking space in Hazaribagh, an urban slum in Dhaka - fixed above the Buriganga river. In these centers, the children sat on the floor and learned informally in flexible shifts according to their working hours. Hence, it did not take lots of resources to introduce these children to their first learning experiences.

Simultaneously to the establishment of this 'hard' infrastructure, i.e. the learning centers, new forms of 'soft' infrastructure, i.e. local institutions, were formed to manage service delivery. All of the seven programs investigated in this case study built up local committees in their centers. These committees were comprised of local government representatives, social workers, parents and sometimes even the employers of child laborers. It could be meaningful to also integrate religious leaders, like the Imam or the Mullah, or other elites from the 
community $^{91}$. In this way, the service-delivering center and institutions became embedded into local societal structures to foster "local ownership" "92 By constantly dealing with the social norms related to the services offered, rights consciousness of the entire community was fostered. Empirically, this became observable when community committees resumed their work even after the externally funded projects had terminated, when they mobilized resources beyond funding periods and when they continued to multiply the message of children's rights $^{93}$. In almost all of the project initiatives, namely CLEP, FFE/PESP, EHCL, BEHTRUWC, ILO/IPEC Net and ILO/IPEC USDoL, indicators for norm consistent community mobilization and local ownership could be observed.

Hence, a first empirical insight of this case study is that the establishment of a local infrastructure for the delivery of rights-related social services and the formation of community institutions are necessary conditions for achieving norm compliance.

\subsection{Socialization Mechanisms}

A further central result of the case study is that a certain configuration of mechanisms needed to be installed to promote norm socialization. The term mechanism will be used in accordance with the research program of 'international socialization' within IR scholarship here. Thus, mechanisms allow for fine-grained explanations on an analytical level below a comprehensive theory ${ }^{94}$.

In Bangladesh, all of the programs considered have utilized forms of targeting. The FFE and its successive PESP programs applied a particularly sophisticated two-step targeting approach. In a first step, economically disadvantaged rural areas, so-called 'thanas, ${ }^{, 95}$, with low education rates were selected. Within these thanas, a household level selection was carried out as the second targeting step; it was relevant to find families with children of primary school age who own less than half an acre of land, whose main income earner is a 
day laborer, and whose household is female-headed or dependent on low-income occupations, such as fishing, pottery, smithery, weaving or cobbling ${ }^{96}$. By applying targeting mechanisms, rights-relevant services, could be directly catered to the neediest children.

Six out of the seven programs worked with advocacy and awareness-raising strategies. Within the framework of the CLEP program, for instance, NGO representatives made use of posters and brochures, but also commenced rallies, workshops and roundtable discussions to explain the meaning of children's rights to the local communities. They even initiated a 'Child Rights Forum' that could be used as a platform for discussion and exchange regarding rights realization and problems accompanying it. This form of dialogue led to a new consciousness among the children themselves; they grew in confidence and approached their social environment - even their employers - with an increased awareness of their own rights. In addition to that, they knew contact points in the centers that supported them in enforcing their rights ${ }^{97}$.

Another necessary condition for withdrawing children from the worst forms of child labor and providing them with basic education and health care services was to offer their adult family members alternative opportunities for income-generation. All of the cases that were considered here pursued such an approach. Reasons why children work are often related to poverty. In poverty contexts, children (not their parents) work under indecent conditions and with low salaries. According to the latest national child labor survey in Bangladesh, about 93.3 percent of child laborers are occupied in the country's informal economy ${ }^{98}$.

Against this background, one component of the ILO/IPEC/Net offered mothers of children engaged in the worst forms of child labor micro-credits and courses to develop entrepreneurial skills to support their way into self-employment. With the help of this mechanism, they shifted dependence on household income from the children to the mothers. Eventually, the women engaged in renting out rickshaws, selling clothes and dishes on the 
market, and printing or doing batik work with textiles. None of their children works anymore; they all became integrated in governmental primary or secondary schools. Women's independent income-earning also led to a strengthening of their decision-making power and, therefore had an empowering effect on women's rights as well. The example of the women's group as one component of ILO/IPEC/Net demonstrates impressively how the mechanisms of income-generation and awareness-raising intertwine and mutually re-enforce each other.

\subsection{Actor Constellations}

In many developing countries, in which the state lacks the required capacities and resources to initiate rights implementation, actor partnerships can - at least temporarily - compensate certain state functions. Such actor constellations, in which state and non-state actors bundle their strengths, are known as public-private-partnerships (PPPs). To pursue common policy goals, partners mutually provide material resources, such as money, infrastructure or other goods, but also exchange immaterial resources, among them knowledge, expertise and information ${ }^{99}$.

In Bangladesh, in five out of the seven cases considered, actor partnerships were built for realizing children's rights. The only projects in which partnerships did not come into existence were the purely governmental FFE/PESP projects as well as the solely nongovernmental CLEP program. Especially when IOs belonged to the initiators of the projects, partnership-building played a central role. In these constellations, however, actors did not have the same rights in agenda-setting and in implementation. The partners also did not dispose of the same decision-making rights and their cooperation is not non-hierarchical.

In contrast to what has been elaborated on $\operatorname{PPPs}^{100}$ so far, this case study demonstrates the emergence of hierarchical partnerships that do not grant the same power in decision-making to the respective actors involved. Instead, the actors initiating the programs, i.e. an IO or the 
government, take over all responsibilities in planning, financing, administrating and monitoring. Local implementation tasks were conducted by NGOs.

What is also different from what has been addressed in IR scholarship yet is the multi-level character of these actor constellations. Here, actors of different levels, i.e. international organizations, national governments and local NGOs, cooperate with each other. Multi-level actor partnerships are (temporarily) formed and each partner pursues its own, delineated scope of duties ${ }^{101}$.

The example of ILO/IPEC/USDoL illustrates how cooperation in such a multi-level partnership is taking shape. To conduct this program, local NGOs had to submit a technical proposal according to the terms of references (ToRs) prepared by the ILO and approved by Bangladesh's MoLE. The ToRs were published in daily newspapers to open a bidding process. Selection criteria included previous performance, professional expertise, and capabilities for providing non-formal education and skills training. On that basis, the ILO contracted NGOs to execute action programs ${ }^{102}$. Hence, NGOs became active at the field level as local implementers paid by the ILO: they took over home visits, any direct interaction with the beneficiaries, their parents and employers, and they formed the required community committees. They saw themselves in the role of a mediator taking over responsibilities in a process that transports norms of international conventions to the local rights-holders ${ }^{103}$.

From this it follows that the most important empirical result of this case study at the actors' level is that the state government has to ratify children's rights norms but that implementation towards societal norm compliance - particularly in weak state contexts - is not always in the hands of the government alone. It delegates planning and decision-making competences to IOs that, with the help of external donors, also provide financial resources and technical expertise. The actual implementation processes, in particular direct interaction with the respective target group, can also be taken over by local NGOs. They have a key role in local 
rights realization because they have privileged access to relevant communities. Here, they establish a new infrastructure and pertinent institutions; they install social mechanisms and act as a multiplier for raising the community's consciousness of children's rights.

This interplay of (infra-)structure and institutions, social mechanisms and actor constellations involved will be summarized in a multi-level model of children's rights implementation in weak states contexts in the following last chapter.

\section{Conclusion: A Multi-level Model for Children's Rights Implementation}

This article has focused on how to comprehensively understand children's rights implementation and how to overcome the discrepancy between global norm ambitions and local realities in the field of children's rights. The central research question examined here was how global children's rights norms become effective for their local targets. To answer this question, a multi-level governance framework was introduced and the following argument was developed: Current international children's rights conventions are characterized by flexibilized principles providing Member States with ample scope for making national implementation decisions and taking the economic situation of developing countries into account. Hand in hand with this flexibilization came increasing ratification rates that - at least formally - indicate recognition of these norms. This formal acceptance has, however, in many countries not necessarily led to a comprehensive change of the children's rights situation at the local level.

In theoretical treatise on rights implementation, there are still desiderata when it comes to explaining how this discrepancy between global norms and local realities can be overcome. This is mainly due to the different foci of relevant scholarship. Norm research in IR mainly focuses on norm adoption (socialization literature) and on norm adherence (compliance literature) at the nation state level. Anthropological research and research on norm 
localization, in contrast, concentrate on the local level without paying attention to the interplay between international, national and local actors and processes. Therefore, a multilevel governance framework seems to be appropriate for understanding children's rights implementation comprehensively.

In the case study on Bangladesh introduced here, an emphasis was placed on understanding steps between national norm acceptance and local changes in the rights situation of children. Altogether, the realization of children's rights can be grasped as a multi-level process as even local level implementation is influenced by multi-level policy programs and actor constellations. In the following, the new findings of the in-depth case study presented, will be integrated - in the form of hypotheses - into a multi-level model on children's rights implementation in weak state contexts. These hypotheses supplement already existing findings from IR scholarship pertinent to the emergence of global norms and their acceptance by nation states. This categorization helps to understand the interplay at different levels of activities of respective steering mechanisms and participating actors. Moreover, it takes up the distinction between norm addressees (i.e. the ratifying state government) and norm targets (i.e. a state's citizens), which is particularly relevant in human rights research. This allows for a more fine-grained differentiation pertinent to which actor is responsible (third column) for an implementation measure and whether this is directed at the norm addressees or the norm targets (fourth and fifth column).

Global norms will continuously be created in the fora of IOs by respective state representatives. To realize them for the rights-holders, a national and a local implementation process need to be accomplished. Both processes are necessary to achieve compliance among the norm addressees, i.e. actors of the state government, and among the norm targets, i.e. the state's population. The processes do not only differ with respect to what actors they are 
directed at, but also regarding the social mechanisms applied and the political level at which they become effective.

In the course of a national implementation process, state actors have to ratify international conventions and transport fundamental standards to national legislation and pertinent policy programs. Moreover, complaint mechanisms and monitoring procedures need to be installed. Their functioning - together with continuous norm-consistent discursive practices of the government - can be viewed as important steps for national implementation ${ }^{104}$.

To progress with local implementation, particularly in weak states, an appropriate infrastructure and administrating institutions have to be established. In a next step, protective measures and social services need to be provided for the norm targets. Awareness raising and income-generating mechanisms usually support this process because they help the target group to actually make use of the services offered. Such mechanisms shall be installed by the responsible state department. If this lacks the required capacities, resources, expertise or access to the target group, it can cooperate with local NGOs and IOs. In these cases, NGOs can function as service providers but they depend on governmental funds, external funding or the channeling of funds through IOs. Their advantage, however, is that they often dispose of particular expertise in the provision of rights-relevant services and that they have strong ties to the local communities. In this way, they act as intermediary actors between state and society, and they can contribute to compensating governmental implementation deficits. But even the rights-holders themselves undertake implementation responsibilities at the local level: once they are persuaded of children's rights, they engage in awareness raising themselves and act as multipliers within their own communities. In some cases, they even start initiating protective measures for other children and their families. 
The following table 3 summarizes the hypotheses on local children's rights implementation generated from this in-depth case study (supplementing already existing insights).

Table 3: A Categorization of Children's Rights Implementation as a Multi-level Process

\begin{tabular}{|c|c|c|c|c|}
\hline level & implementation measure & actors & addressee & target \\
\hline global & norm creation & IOs \& governments & government & \\
\hline national & $\begin{array}{l}\text { ratification, making norms } \\
\text { effective in national } \\
\text { legislation and domestic } \\
\text { policies }\end{array}$ & IOs \& government & government & \\
\hline \multirow[t]{3}{*}{ local } & $\begin{array}{l}\text { establishing local } \\
\text { infrastructure \& institutions }\end{array}$ & $\begin{array}{l}\text { IOs \& government } \\
\& \text { local NGOs }\end{array}$ & & rights-holders \\
\hline & $\begin{array}{l}\text { installing mechanisms } \\
\text { (material mechanisms, i.e. } \\
\text { income-generation \& } \\
\text { immaterial mechanisms, } \\
\text { i.e. awareness raising) }\end{array}$ & $\begin{array}{l}\text { IOs \& government } \\
\& \text { local NGOs \& } \\
\text { rights-holders }\end{array}$ & & rights-holders \\
\hline & $\begin{array}{l}\text { effecting protective } \\
\text { measures \& rights-related } \\
\text { services }\end{array}$ & $\begin{array}{l}\text { IOs \& government } \\
\& \text { local NGOs \& } \\
\text { rights-holders }\end{array}$ & & rights-holders \\
\hline
\end{tabular}

Finally, two constraints to these results shall be briefly discussed. First, the study on Bangladesh introduced here is a single case study. The hypotheses generated in the course of the empirical analysis still have to be tested in other local contexts of other world regions in order to allow more generalizable claims. Thus, further research and case studies are needed. Second, all of the seven policy programs analyzed here are of a temporary nature. Hence, funding is usually dependent on external donor money and can only be secured within the limited time frame of project duration. Afterwards, the government is responsible for taking over the established infrastructure and for rights-relevant services. This means that multi-level 
actor partnerships can only temporarily compensate local implementation deficits and state capacities need to be strengthened in the long run in order to achieve sustainability. 


\footnotetext{
${ }^{1}$ Nobelprize, 'The Nobel Peace Prize for 2014', \{http://www.nobelprize.org/nobel_prizes/peace/laureates/2014/press.html\} accessed 31 January 2015.

${ }^{2}$ Ulrich Schneckener, 'Fragile Staatlichkeit und Statebuilding: Begriffe, Konzepte und Analyserahmen', in Marianne Beisheim and Gunnar Folke Schuppert (eds.), Staatszerfall und Governance (Baden-Baden: Nomos, 2007), pp.107-9.

${ }^{3}$ Thomas Risse, 'Governance in Areas of Limited Statehood: Introduction and Overview', in Thomas Risse
} (ed.), Governance without a State? Policies and Politics in Areas of Limited Statehood (New York: Columbia University Press, 2011), pp.2-3.

${ }^{4}$ In this article, the term mechanism is used to explain how norm socialization and compliance can be fostered. In this regard, mechanisms can be understood as a set of hypotheses explaining a specific social phenomenon with regard to interactions among individuals and interactions between individuals and some sort of social aggregate. They enable fine-grained explanations operating at an analytic level below that of a comprehensive theory (compare Jeffrey T. Checkel, 'It's the Process Stupid! Process Tracing in the Study of European and International Politics', Centre for European Studies, (University of Oslo: ARENA Working Paper, 2005). 5 e.g. Thomas Risse, Stephen C. Ropp and Kathryn Sikkink (eds.), 'The Persistent Power of Human Rights: From Commitment to Compliance' (Cambridge: Cambridge University Press, 2013).

${ }^{6}$ Amitav Acharya, 'How Ideas Spread: Whose Norms Matter? Norm Localization and Institutional Change in Asian Regionalism', International Organization 58 (2004), pp.239-275; Sally E. Merry, 'Human Rights and Gender Violence: Translating International Law into Local Justice’ (Chicago/London: Chicago University Press, 2006).

${ }^{7}$ Simmons recently pointed out that: "The most interesting research to date has been precisely on the specification of mechanisms linking domestic and transnational politics [...]" Beth Simmons, 'From Ratification to Compliance: Quantitative Evidence on the Spiral Model', in Risse, Ropp and Sikkink, 'The Persistent Power of Human Rights', p.58.

${ }^{8}$ UNTC, 'United Nations Treaty Collection: Convention on the Rights of the Child' (2015), \{https://treaties.un.org/Pages/ViewDetails.aspx?src=TREATY\&mtdsg_no=IV-11\&chapter=4\&lang=en \} accessed 07 August 2015.

${ }^{9}$ UNICEF, 'The State of the World's Children 2014' (New York: United Nations International Children's Emergency Fund, 2014); ILO, 'Accelerating Action against Child Labour' (Geneva: International Labour Office, 2010).

${ }^{10}$ John Gerring 'Case Study Research: Principles and Practices' (Cambridge: Cambridge University Press, 2007).

${ }^{11}$ Sumaiya Khair, 'Child Labour in Bangladesh: A Forward Looking Policy Study', Centre for Policy Dialogue, (Geneva: International Programme on the Elimination of Child Labour, International Labour Office, 2005).

${ }^{12}$ Bernhard Ebbinghaus, 'When Less is More: Selection Problems in Large-N and Small-N Cross-national Comparisons', International Sociology, 20:2 (2005), p.142.

${ }^{13}$ Alexander L. George and Andrew Bennett, 'Case Studies and Theory Development in the Social Sciences' (Cambridge: MIT Press, 2005).

${ }^{14}$ Gerring, 'Case Study Research', p.17.

${ }^{15}$ Andreas Witzel and Herwig Reiter, 'The Problem-Centred Interview' (London: SAGE, 2012).

${ }^{16}$ Benoît Rihoux and Charles C. Ragin, 'Configurational Comparative Methods: Qualitative Comparative Analysis (QCA) and Related Techniques' (London: SAGE, 2009).

${ }^{17}$ Philipp Mayring, 'Qualitative Content Analysis. Theoretical Foundation, Basic Procedures and Software Solution (Social Science Open Access Repository SSOAR), available at:

\{http://nbnresolving.de/urn:nbn:de:0168-ssoar-395173\} accessed 07 August 2015; Michael Meuser and Ulrike Nagel, 'ExpertInneninterviews - vielfach erprobt, wenig bedacht: Ein Beitrag zur qualitativen

Methodendiskussion', in Alexander Bogner, Beate Littig and Wolfgang Menz (eds.), Das Experteninterview: Theorie, Methode, Anwendung (Wiesbaden: VS Sozialwissenschaften, 2005), pp.71-94;

${ }^{18}$ William F. Whyte, 'Learning from the Field: A Guide from Experience' (Beverly Hills: SAGE, 1984).

${ }^{19}$ Kenneth Abbott and Duncan Snidal, 'Strengthening International Regulation through Transnational New Governance: Overcoming the Orchestration Deficit', Vanderbilt Journal of Transnational Law, 42:2 (2009), p.530.

${ }^{20} \mathrm{UN}$, 'Convention on the Rights of the Child', Adopted and opened for signature, ratification and accession by General Assembly resolution 44/25 of 20 November 1989.

${ }^{21}$ e.g. Jean Grugel and Enrique Peruzzotti, 'The Domestic Politics of International Human Rights Law: Implementing the Convention on the Rights of the Child in Ecuador, Chile, and Argentina', Human Rights Quartely, 34: 1 (2012), pp.178-198. 
${ }^{22}$ ILO, 'Minimum Age Convention C138', Adopted by the General Conference of the International Labour Organization, 58th Session in Geneva.

${ }^{23}$ ILO, 'Worst Forms of Child Labour Convention C182', Adopted by the General Conference of the International Labour Organization, 87th Session in Geneva.

${ }^{24}$ William E. Myers, 'The Right Rights? Child Labor in a Globalizing World', The Annals of the American Academy of Political and Social Science, 575:1 (2001), pp.51-2.

${ }^{25}$ UNTC, 'Convention on Rights of Child'.

${ }^{26}$ NORMLEX, 'Ratifications of C182 - Worst Forms of Child Labour Convention 1999' (2014a), available at: \{http://www.ilo.org/dyn/normlex/en/f?p=1000:11300:0::NO:11300:P11300_INSTRUMENT_ID:312327 \} accessed 31 January 2015.

${ }^{27}$ NORMLEX, 'Ratifications of C138 - Minimum Age Convention 1973' (2014b), available at: \{http://www.ilo.org/dyn/normlex/en/f?p=1000:11300:0::NO:11300:P11300_INSTRUMENT_ID:312283 \} accessed 08 August 2015.

${ }^{28}$ Pamela Reynolds, Olga Nieuwenhuys and Karl Hanson, 'Refractions of Children's Rights in Development Practice: A View from Anthropology', Childhood, 13:3 (2006), p.298.

${ }^{29}$ ILO, 'Making Progress Against Child Labour: Global Estimates and Trends 2000-2012', (Geneva:

International Labour Office, 2013), p.3.

${ }^{30}$ UNICEF, 'The State of the World's Children 2014', p.23-8.

${ }^{31}$ UNICEF and UNESCO, 'Envisioning Education in the Post-2015 Development Agenda' (New York and Paris: United Nations International Children's Emergency Fund and United Nations Educational, Scientific and Cultural Organization, 2013), p.3.

${ }^{32}$ Emilie M. Hafner-Burton and Kiyoteru Tsutsui, 'Human Rights in a Globalizing World: The Paradox of Empty Promises', American Journal of Sociology, 110:5 (2005).

${ }^{33}$ Ronald L. Jepperson, Alexander Wendt and Peter J. Katzenstein, 'Norms, Identity and Culture in National Security', in Peter J. Katzenstein, Peter J. (ed.), The Culture of National Security: Norms and Identity in World Politics (New York: Columbia University Press, 1996), pp.33-75.

${ }^{34}$ Hans Peter Schmitz and Kathryn Sikkink, 'International Human Rights', in Walter Carlsnaes, Thomas Risse and Beth A. Simmons (eds.), Handbook of International Relations (London: SAGE, 2013), pp.827-51.

${ }^{35}$ Martha Finnemore and Kathryn Sikkink, 'Norm Dynamics and Political Change', International Organization, 52:4 (1998), pp.902-909.

${ }^{36}$ Thomas Risse, Stephen C. Ropp and Kathryn Sikkink (eds.), 'The Power of Human Rights. International Norms and Domestic Change' (Cambridge: Cambridge University Press, 1999).

${ }^{37}$ Frank Schimmelfennig, 'Internationale Sozialisation: Von einem "erschöpften" zu einem produktiven Forschungsprogramm?', in Gunther Hellmann, Klaus Dieter Wolf and Michael Zürn (eds.), 'Die neuen Internationalen Beziehungen. Forschungsstand und Perspektiven in Deutschland' (Baden-Baden: Nomos, 2002), pp.405-7.

${ }_{38}^{38}$ Chayes, Chayes and Mitchell, 'Managing Compliance', p.39.

${ }^{39}$ Risse, Ropp and Sikkink, 'The Persistent Power of Human Rights'.

${ }^{40}$ Michael Zürn and Christian Joerges (eds.), 'Law and Governance in Postnational Europe: Compliance Beyond the Nation State' (Cambridge: Cambridge University Press, 2005).

${ }^{41}$ ibid., p.26.

${ }^{42}$ Reynolds, Nieuwenhuys and Hanson, 'Refractions of Children's Rights', p.298.

${ }^{43}$ Jo Boyden, Birgitta Ling and William Myers, 'What Works for Working Children' (Stockholm: Rädda Barnen, 1998).

${ }^{44}$ James, 'Giving Voice to Children's Voices', p.270.

${ }^{45}$ Sally E. Merry, 'Human Rights and Gender Violence: Translating International Law into Local Justice'

${ }^{46}$ ibid: pp.39-42.

${ }^{47}$ ibid.

${ }^{48}$ Sally E. Merry, Peggy Levitt, Mihaela S. Rosen and Diana H. Yoon, 'Law From Below: Women's Human Rights and Social Movements in New York City', Law \& Society Review, 44:1 (2010), p.102.

${ }^{49}$ James Rosenau, 'Governance in the Twenty-First Century', Global Governance 1:2 (1995), p.13.

${ }^{50}$ e.g. Beate Kohler-Koch and Berthold Rittberger, 'A Futile Quest for Coherence: The Many Frames of EU Governance', in Beate Kohler-Koch and Fabrice Larat (eds.), European Multi-Level Governance (Cheltenham: Edward Elgar, 2009), pp.3-18.

${ }^{51}$ Arthur Benz, 'Politik in Mehrebenensystemen' (Wiesbaden: VS Verlag, 2009), pp.17-8.

${ }^{52}$ Bob Deacon, 'Global Social Policy and Governance' (London: SAGE).

${ }^{53}$ Michael Zürn, 'Global Governance as Multi-Level Governance' in David Levi-Faur (ed.), Oxford Handbook of Governance (Oxford: Oxford University Press, 2012), p.731. 
${ }^{54}$ Amitav Acharya, 'How Ideas Spread: Whose Norms Matter? Norm Localization and Institutional Change in Asian Regionalism'.

${ }^{55}$ Anne Jenichen and Andrea Schapper, 'From Global Ambitions to Local Change: How Multi-Level

Cooperation Advances Norm Implementation in Weak State Contexts', Journal of International Relations and Development (2015), doi:10.1057/jird.2014.29.

${ }^{56}$ Khair, 'Child Labour', p.20.

${ }^{57}$ NORMLEX, 'Information System on International Labour Standards', available at:

\{http://www.ilo.org/dyn/normlex/en/f?p=1000:11200:0::NO:11200:P11200_COUNTRY_ID:103500\} accessed 14 June 2014.

${ }^{58}$ Interview Tapan Kumar Chakravorty, Ministry of Primary and Mass Education, Primary Education Stipend Project, Deputy Director, 17 July 2008.

${ }^{59}$ Kamal Siddiqui, 'Better Days, Better Lives: Towards a Strategy for Implementing the Convention on the Rights of the Child in Bangladesh' (Dhaka: The University Press Limited, 2003), p.19.

${ }^{60}$ Atiur Rahman, Mahfuz Kabir and Muksudul A. Alam, 'Public Expenditure in Primary Education in Bangladesh: An Analysis', (Dhaka: Shamunnay, 2005), p.8.

${ }^{61}$ Akhter U. Ahmed and Carlo del Ninno, 'The Food for Education Program in Bangladesh: An Evaluation of its Impact on Educational Attainment and Food Security', FCND Discussion Paper No. 138 (Washington: International Food Policy Research Institute, 2002), p.16.

${ }^{62}$ UNICEF, 'The State of the World's Children 2014', p.104.

${ }^{63}$ Fadia Sultana and Mohiuddin Ahmed, 'Chapter Two: Child Health and Nutrition', in Child Rights: Reality and Challenges (Dhaka: The British Council, 2001), p.33-50.

${ }^{64}$ Bangladesh Labour Code, (Dhaka, Bangladesh: CCB Foundation, 2006).

${ }^{65}$ MoLE, 'National Child Labour Elimination Policy 2010', Ministry of Labour and Employment (Dhaka: Government of Bangladesh, 2010), pp.4-5.

${ }^{66}$ Targeted number refers to the quantity of children the respective project aimed to reach. This quantity, however, varies significantly among the projects considered here.

${ }^{67}$ During field research, it was not possible to gather data on projects that were completely unsuccessful.

${ }^{68}$ Funded by the US Department of Labor.

${ }^{69}$ Funded by the Netherlands.

${ }^{70}$ Output comprises the protection measures and services offered by the programs. If children and their families utilized them, an outcome could be observed; see also Arild Underdal, 'Methodological Challenges in the Study of Regime Effectiveness', in Arild Underdal and Oran R. Young (eds.) 'Regime Consequences: Methodological Challenges and Research Strategies', Dordrecht: Kluwer (2004), pp.27-48.

${ }^{71}$ Benoît Rihoux and Charles C. Ragin, 'Configurational Comparative Methods', p.91.

${ }^{72}$ Data obtained from e-mail correspondence with Sajjad Hossain (Project Coordinator of BILS/CLEP), 7

November 2009.

${ }^{73}$ Interview Chakravorty.

${ }^{74}$ GoB, 'Draft Mid-Term Evaluation Report of The Basic Education for Hard to Reach Urban Working Children's Project' (Dhaka: Government of Bangladesh, 2008), p.13.

${ }^{75}$ ILO/IPEC, 'Preventing and Eliminating the Worst Forms of Child Labour in Selected Formal and Informal Sectors in Bangladesh BGD/00/P50/USA, Independent Mid-term Project Evaluation ', Geneva: ILO/IPEC Design, Evaluation and Documentation Section, 2003), p.16.

${ }^{76}$ ILO/IPEC, 'Prevention and Elimination of Selected Worst Forms of Child Labour in the Informal Economy in Dhaka City BGD/00/P01/NET, Independent Final Evaluation', Geneva: ILO/IPEC Design, Evaluation and Documentation Section, 2006), p.23

${ }^{77}$ Mathew J. Bannermann and Ronald E. Berghuys, 'Breaking the Cycle: Key Learning from an ILO-IPEC Project in Bangladesh' (Dhaka: International Labour Office, 2008), p.41.

${ }^{78}$ ibid: p. 30 .

${ }^{79}$ ibid: p. 43

${ }^{80}$ ibid: p.36, 42.

${ }^{81}$ ILO/IPEC, 'Combined Evaluation of ILO/IPEC Garment Sector Projects, Final Project Evaluation', Geneva: ILO-IPEC Design, Evaluation and Documentation Section, 2004), p.2.

${ }^{82}$ ILO/IPEC, 'ILO/IPEC BGMEA Phase III - Continuing the Child Labour Monitoring and Education Components and Prepare for the Integration Into a Broader Project in the Garment Export Industry BGD/00/52/USA, Final Evaluation', (Geneva: ILO-IPEC Design, Evaluation and Documentation Section, 2004), p.22.

${ }^{83}$ ILO/UNICEF, 'Addressing Child Labour in the Bangladesh Garment Industry 1995-2001: A Synthesis of UNICEF and ILO Evaluation Studies of the Bangladesh Garment Sector Projects', (New York and Geneva: ILO and UNICEF, 2004), p.9. 
${ }^{84}$ ILO/IPEC, 'ILO/IPEC BGMEA Phase III'

${ }^{85}$ UNDP Bangladesh, 'Reduce Child Mortality', available at:

\{http://www.bd.undp.org/content/bangladesh/en/home/mdgoverview/overview/mdg4.html\}, accessed 8 August 2015.

${ }^{86}$ Benoît Rihoux and Charles C. Ragin, 'Configurational Comparative Methods'.

${ }^{87}$ Interview Mohammad Golam Kibria, Education Officer, UNICEF (4 June 2008).

${ }^{88}$ Interview Sanwar Moni, Coordinator Executive Director's Secretariat, Padakhep (1 July 2008).

${ }^{89}$ Non-formal education (NFE) is a form of flexible schooling outside the formal governmental education system, often managed by NGOs.

${ }_{90}^{90}$ Interview Kibria.

${ }^{91}$ Children's rights situation is never independent of the socio-economic and political situation of their family and community: Zehra F. Arat, 'Analyzing Child Labor as a Human Rights Issue: Its Causes, Aggravating Policies, and Alternative Proposals', Human Rights Quarterly 24:1 (2002), pp.177-204.

${ }_{92}$ Interview Ronald E. Berghuys, ILO/IPEC Chief Technical Advisor, (19 May 2008).

${ }_{93}^{93}$ Interview Shahid Uz Zaman, Executive Director, Eco-Social Development Organization (6 July 2008).

${ }^{94}$ Checkel, 'It's the Process Stupid!'

${ }^{95}$ Administrative unit below the level of a district or division.

${ }^{96}$ Xin Meng and Jim Ryan, 'Evaluating the Food for Education Program in Bangladesh', Department of Economics Research School of Pacific and Asian Studies, Canberra: Australian National University.

${ }^{97}$ Interview Hossain.

${ }^{98}$ BBS, 'Report on National Child Labour Survey', (Dhaka: Bangladesh Bureau of Statistics, 2003), pp.61-3.

${ }^{99}$ Carmen Huckel, Lothar Rieth and Melanie Zimmer, 'Die Effektivität von Public-Private Partnerships', in Andreas Hasenclever, Klaus Dieter Wolf and Michael Zürn (eds.), Macht und Ohnmacht internationaler Institutionen. Festschrift für Volker Rittberger (Frankfurt/ New York: Campus, 2007), pp.115-44. ${ }^{100}$ ibid.

${ }^{101}$ Andrea Schapper, 'From the Global to the Local: How International Rights Reach Bangladesh's Children' (London: Routledge), pp.126-41.

${ }^{102}$ Interview Nazrul Islam Miah, Administrative and Finance Assistant, ILO (24 June 2008).

${ }^{103}$ Interview Md. Hamidul Islam, Assistant Director, Bangladesh Development Service Center (24 May 2008).

${ }^{104}$ Risse, Ropp and Sikkink, 'Power of Human Rights', p.29. 